\title{
STUDY ON MEASURING THE PERFORMANCE OF THE EDUCATION SYSTEM WITH THE HELP OF KEY PERFORMANCE INDICATORS
}

\author{
Ioan VIRCA \\ virca_ioan@yahoo.com \\ Maria-Lucia RUSU \\ rusu.maria@armyacademy.ro
}

“NICOLAE BĂLCESCU” LAND FORCES ACADEMY, SIBIU, ROMANIA

\begin{abstract}
The paper carries out a study based on the procedural approach of quality management in the educational system, with application on the military field, in order to measure organizational performance. Therefore, the evaluation methodology comprises a series of steps that can be found as subchapters in the paper. The procedural approach of performance evaluation allows the development of an integrated vision of the interdependencies and interactions between the specific processes, which favors an efficient analysis of the quality and quantity of the obtained results. The conclusions of the analysis are materialized in measures to improve the organizational processes, thus contributing to the achievement of an efficient quality management in the educational system.
\end{abstract}

\section{KEYWORDS:}

Procedural approach, key performance indicators, educational system

\section{Introduction}

In the educational system, the measurement of organizational performance is an important stage of the process of evaluating the finalities of the educational act and "consists in monitoring quantifiable and relevant results that can provide an objective evaluation of performance" (BâtcăDumitru, 2019). Increasing educational performance in the case of the military education system - as a subject of analysis and research of this study is the general institutional objective itself, expressed as follows "Increasing the performance of educational management specific to the training of commanding officers in accordance with the real professionalization needs of the Land Forces personnel and the requirements of aligning military higher education with the Euro-Atlantic area and maximizing institutional functionality in the context of implementing the concept of transforming military higher education" ("Nicolae Bălcescu" Land Forces Academy, 2020).

An objective measurement of the performances achieved in the educational system is made with the help of the so-called key performance indicators KPI, which represent "... a tool for measuring 
the degree of accomplishment of an activity carried out by an organization that provides education by reference to a standard. Performance indicators identify those results that range from a minimum acceptable level to a maximum identifiable level", (Romanian Agency for Quality Assurance in Higher Education, 2006, p. 6).

Thus, in order to establish the performance indicators and their target, the organization's processes are identified in advance, in this case the university, then at the end of the monitored period the indicators are analyzed in order to achieve the proposed targets, and finally an improvement plan is elaborated of the processes and indicators that have not reached their target and decisions are made to implement improvement solutions. All these steps are the component elements of the organizational performance appraisal system which "... should be used as a tool to identify problems, correct performance deficiencies and improve work behaviors and not as a means of detecting mistakes and of applying corrections" (Dumitrașcu \& Ciupitu, 2013). Indeed, increasing or correcting performance can be achieved only by improving the professional and attitudinal behavior of the human factor of the organization - teachers and auxiliary staff, research staff, administrative staff and last but not least students, master students, doctoral students.

\section{Identifying the processes within the organization}

To correctly identify the processes of an organization, one of the eight principles of quality management is used, namely "approach as a process" (Romanian Standardization Association). The procedural approach allows the establishment of the organization's processes and their inclusion in an integrated system, aiming to improve the results of the processes and thus increase the performance of the educational system.

According to this type of approach, organizational processes are classified into three categories: management processes, main processes and support processes. In the educational field, management processes refer to the mission of the university, institutional strategies and programs, general and specific objectives, management of all resources, internal managerial control, etc. The main processes aim at the operational transposition of the preparation requirements of the beneficiaries towards the finished product, i.e. the graduate of the institution, creating for him / her the established profile. Support processes include the range of services that meet all the requirements and obligations of both students and the institution in relation to them.

Thus, for the military education system the following processes can be identified, grouped on the three categories listed above:

a. Management processes:

- Mission and objectives

- Strategy and programs

- Resource insurance

- Internal managerial control

b. Main processes:

- Graduate's profile

- Educational management

- Training requirements

- Finished product - the graduate

- University training: bachelor's and master's degrees

- Military training: basic and specialized

- Physical and sports training

c. Support processes:

- Financial insurance

- Accommodation and meals for students

- Human resources

- Psychological and medical assistance

- Investments / acquisitions of equipment and materials

- Protection and security.

All identified processes are represented in Figure no. 1 in the form of a map of processes, being a scheme that reflects how processes are conditioned at the level of the institution. The map of processes is a basic element in establishing performance indicators. 


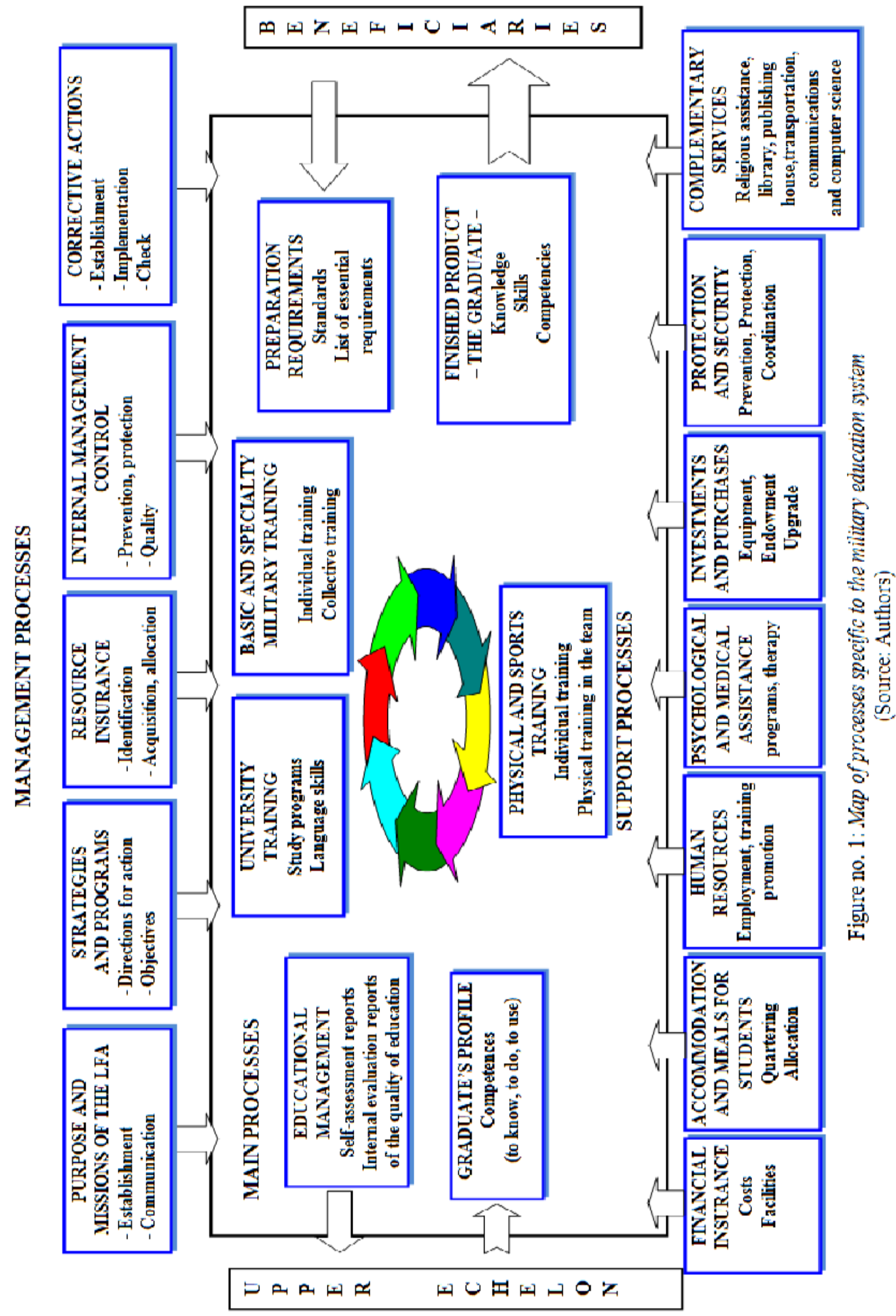


3. Elaboration of the process sheet and the list of specific activities and objectives

The next stage of establishing the performance indicators is the elaboration of the process sheet, which has the role of synthesizing the flow of the transformation of the input data into output data for each process, specifying the related resources and process managers.
In Table no. 1 two processes are analyzed, a main one - physical and sports training and a support one - human resources. Furthermore, for reasons related to the size of this paper, according to the publication's template, the research will focus only on the two processes, as a model of analysis for other processes or for the whole system as a whole.

Table no. 1

Process sheet for the considered processes

\begin{tabular}{|c|c|c|c|c|}
\hline $\begin{array}{c}\text { Process } \\
\text { name }\end{array}$ & Input data & Output data & Resources & $\begin{array}{l}\text { Process } \\
\text { manager }\end{array}$ \\
\hline $\begin{array}{l}\text { Physical } \\
\text { and } \\
\text { sports } \\
\text { training } \\
\text { (main } \\
\text { process) }\end{array}$ & $\begin{array}{l}\text { 1. Sports training } \\
\text { management } \\
\text { documents (curriculum, } \\
\text { course syllabus) } \\
\text { 2. Training regulations, } \\
\text { courses, manuals } \\
\text { 3. Methodologies, } \\
\text { norms, standards, } \\
\text { evaluation scales } \\
\text { 4. Initial evaluation } \\
\text { 5. Orientation and } \\
\text { estimation programs } \\
\text { for the evolution of } \\
\text { physical training } \\
\text { 6. Competition offers }\end{array}$ & $\begin{array}{l}\text { 1. Results } \\
\text { 2. Evolution } \\
\text { forms / periodic } \\
\text { follow-up of } \\
\text { the training } \\
\text { 3. Final } \\
\text { evaluation } \\
\text { forms } \\
\text { 4. Grades' book } \\
\text { 5. Evaluation } \\
\text { sheets of the } \\
\text { teacher's } \\
\text { activity by the } \\
\text { students } \\
6 \text {. Prizes, } \\
\text { trophies }\end{array}$ & $\begin{array}{l}\text { - Human } \\
\text { (students, } \\
\text { teachers, } \\
\text { instructors, } \\
\text { trainers) } \\
\text { - Financial } \\
\text { (ensuring and } \\
\text { maintaining the } \\
\text { functionality of } \\
\text { the sports } \\
\text { facilities) } \\
\text { - Information } \\
\text { (IT and } \\
\text { monitoring } \\
\text { equipment) }\end{array}$ & $\begin{array}{l}\text { Head of the } \\
\text { didactic } \\
\text { commission } \\
\text { "Physical and } \\
\text { sports training" }\end{array}$ \\
\hline $\begin{array}{l}\text { Human } \\
\text { resources } \\
- \\
\text { teaching } \\
\text { staff } \\
\text { (support } \\
\text { process) }\end{array}$ & $\begin{array}{l}\text { 1. Specific } \\
\text { documents, job } \\
\text { descriptions, } \\
\text { operational } \\
\text { procedures } \\
\text { 2. National } \\
\text { legislation, } \\
\text { professional } \\
\text { standards } \\
\text { 3. Activity indicators } \\
\text { 4. Performance } \\
\text { review form } \\
\text { 5. Requirements and } \\
\text { proposals for } \\
\text { improvement }\end{array}$ & $\begin{array}{l}\text { 1. Evaluation } \\
\text { forms } \\
\text { 2. Appreciation } \\
\text { ratings } \\
\text { 3. Training } \\
\text { programs } \\
\text { 4. Promotion } \\
\text { needs } \\
\text { 5. Personal } \\
\text { satisfaction } \\
\text { assessment } \\
\text { questionnaires }\end{array}$ & $\begin{array}{l}\text { - Human } \\
\text { - Financial } \\
\text { - Technical } \\
\text { - Information }\end{array}$ & $\begin{array}{l}\text { Head of human } \\
\text { resources } \\
\text { department }\end{array}$ \\
\hline
\end{tabular}


The two processes analyzed were chosen due to the significant share of physical and sports training in the basic training of a military and the importance of human resources in personnel records, personal data processing, transmission of specific documents to beneficiaries and management of career development.

The complete establishment of the input data is very important because they determine the evolution of the final product during a long educational process. Thus, at the end of it, the process sheet provides data on the evaluation framework of the profile and potential of the final product.

Table no. 2 presents the List of specific activities and specific objectives derived from the considered processes. Their establishment takes into account both the observance of the specific attributions of the divisions / departments responsible for the process in question, and the specification of some documents that regulate the specific activities.

Table no. 2

List of specific activities and specific objectives

\begin{tabular}{|c|c|c|}
\hline Process & Specific activities & Annual specific objectives \\
\hline \multirow{6}{*}{$\begin{array}{l}\text { Physical and } \\
\text { sports } \\
\text { training }\end{array}$} & \multirow{2}{*}{$\begin{array}{l}\text { Organizing, planning } \\
\text { and evaluating physical } \\
\text { and sports activity }\end{array}$} & $\begin{array}{l}\text { Planning activities according to the availability } \\
\text { of teachers and the existing facilities (training } \\
\text { gyms, outdoor tracks, gymnastics porticos, etc.) }\end{array}$ \\
\hline & & $\begin{array}{l}\text { Continuing with the physical and sports } \\
\text { training of students }\end{array}$ \\
\hline & \multirow{2}{*}{$\begin{array}{l}\text { Participation in national } \\
\text { and international } \\
\text { competitions }\end{array}$} & $\begin{array}{l}\text { Planning the internal competition calendar, in } \\
\text { accordance with the annual calendar of the } \\
\text { own ministry and the invitations to participate } \\
\text { in the international competitions and the } \\
\text { concluded agreements }\end{array}$ \\
\hline & & $\begin{array}{l}\text { Obtaining meritorious places at sports } \\
\text { competitions and contests (I, II, III places, } \\
\text { certificates of merit) }\end{array}$ \\
\hline & \multirow{2}{*}{$\begin{array}{l}\text { Improving the training } \\
\text { facilities }\end{array}$} & Inventory of the training facilities \\
\hline & & $\begin{array}{l}\text { Completing the training facilities by fulfilling } \\
\text { the Annual Procurement Plan }\end{array}$ \\
\hline \multirow{6}{*}{$\begin{array}{l}\text { Human } \\
\text { resources - } \\
\text { academic / } \\
\text { teaching staff }\end{array}$} & \multirow{2}{*}{$\begin{array}{l}\text { Organizing the } \\
\text { competition for the } \\
\text { teaching staff and } \\
\text { occupying the positions }\end{array}$} & $\begin{array}{l}\text { Completing the organizational chart of the } \\
\text { departments within the faculties }\end{array}$ \\
\hline & & $\begin{array}{l}\text { Establishing the commissions for the analysis } \\
\text { of the competition files and of the } \\
\text { commissions for organizing the competitions } \\
\text { to occupy the positions }\end{array}$ \\
\hline & \multirow{2}{*}{$\begin{array}{l}\text { Annual evaluation of } \\
\text { the teachers }\end{array}$} & $\begin{array}{l}\text { Carrying out the annual evaluation activity } \\
\text { according to the specific legislation }\end{array}$ \\
\hline & & $\begin{array}{l}\text { Analysis of the results obtained by teachers at } \\
\text { the annual evaluation }\end{array}$ \\
\hline & \multirow{2}{*}{$\begin{array}{l}\text { Improving the } \\
\text { professional activity of } \\
\text { teachers }\end{array}$} & Annual promotion of teachers \\
\hline & & $\begin{array}{l}\text { Elaborating the Annual Plan for professional } \\
\text { training of teachers }\end{array}$ \\
\hline
\end{tabular}




\section{Establishing performance indicators and their goal}

The choice of the most relevant key performance indicators in the education system must be made so that the main and support processes can realistically favor the achievement of the proposed objectives for each set indicator. Thus, the institution must have clearly defined processes with measurable objectives, results could be measured qualitatively and quantitatively, and deviations could be corrected to meet short-term objectives.

Table no. 3

Performance indicators and their goals

\begin{tabular}{|c|c|c|c|c|}
\hline No. & Process & $\begin{array}{l}\text { General objective (GO) and } \\
\text { annual specific objectives } \\
\text { (SO) }\end{array}$ & $\begin{array}{l}\text { Performance } \\
\text { indicator }\end{array}$ & Goal \\
\hline \multirow[t]{4}{*}{1.} & \multirow[t]{4}{*}{$\begin{array}{l}\text { Physical } \\
\text { and sports } \\
\text { training }\end{array}$} & $\begin{array}{l}\text { GO: Increasing the level of } \\
\text { physical and sports training } \\
\text { of students by applying the } \\
\text { Concept of military and } \\
\text { sports training of students in } \\
\text { the academic year 2020-2021 }\end{array}$ & $\begin{array}{l}\text { The level of } \\
\text { physical and sports } \\
\text { training of the } \\
\text { students at the } \\
\text { final annual } \\
\text { evaluation 2020- } \\
2021\end{array}$ & $\begin{array}{l}\text { Obtaining the } \\
\text { "Exceptional" } \\
\text { score, in a } \\
\text { percentage } \\
\text { between } 85 \% \text { of } \\
\text { the total number of } \\
\text { students }\end{array}$ \\
\hline & & $\begin{array}{l}\text { SO: Continuing students' } \\
\text { physical and sports training }\end{array}$ & $\begin{array}{l}\text { The level of } \\
\text { participation in } \\
\text { the physical and } \\
\text { sports training } \\
\text { activities planned } \\
\text { in the academic } \\
\text { year 2020-2021 }\end{array}$ & $\begin{array}{l}90 \% \text { attendance to } \\
\text { class }\end{array}$ \\
\hline & & $\begin{array}{l}\text { SO: Obtaining meritorious } \\
\text { places at sports competitions } \\
\text { and contests (I, II, III places, } \\
\text { certificates of merit) }\end{array}$ & $\begin{array}{l}\text { The results } \\
\text { obtained at the } \\
\text { sports } \\
\text { competitions } \\
\text { planned in the } \\
\text { 2020-2021 } \\
\text { calendar }\end{array}$ & $\begin{array}{l}\text { Obtaining the first } \\
\text { place in at least } \\
75 \% \text { of the } \\
\text { participations }\end{array}$ \\
\hline & & $\begin{array}{l}\text { SO: Improving the training } \\
\text { facilities by fulfilling the } \\
\text { Annual Procurement Plan }\end{array}$ & $\begin{array}{l}\text { Insuring the } \\
\text { acquisition } \\
\text { percentage to } \\
\text { complete the } \\
\text { facilities needs }\end{array}$ & $\begin{array}{l}\text { Reaching the } \\
\text { percentage of } \\
100 \% \text { of the } \\
\text { provisions of the } \\
\text { Procurement Plan }\end{array}$ \\
\hline
\end{tabular}




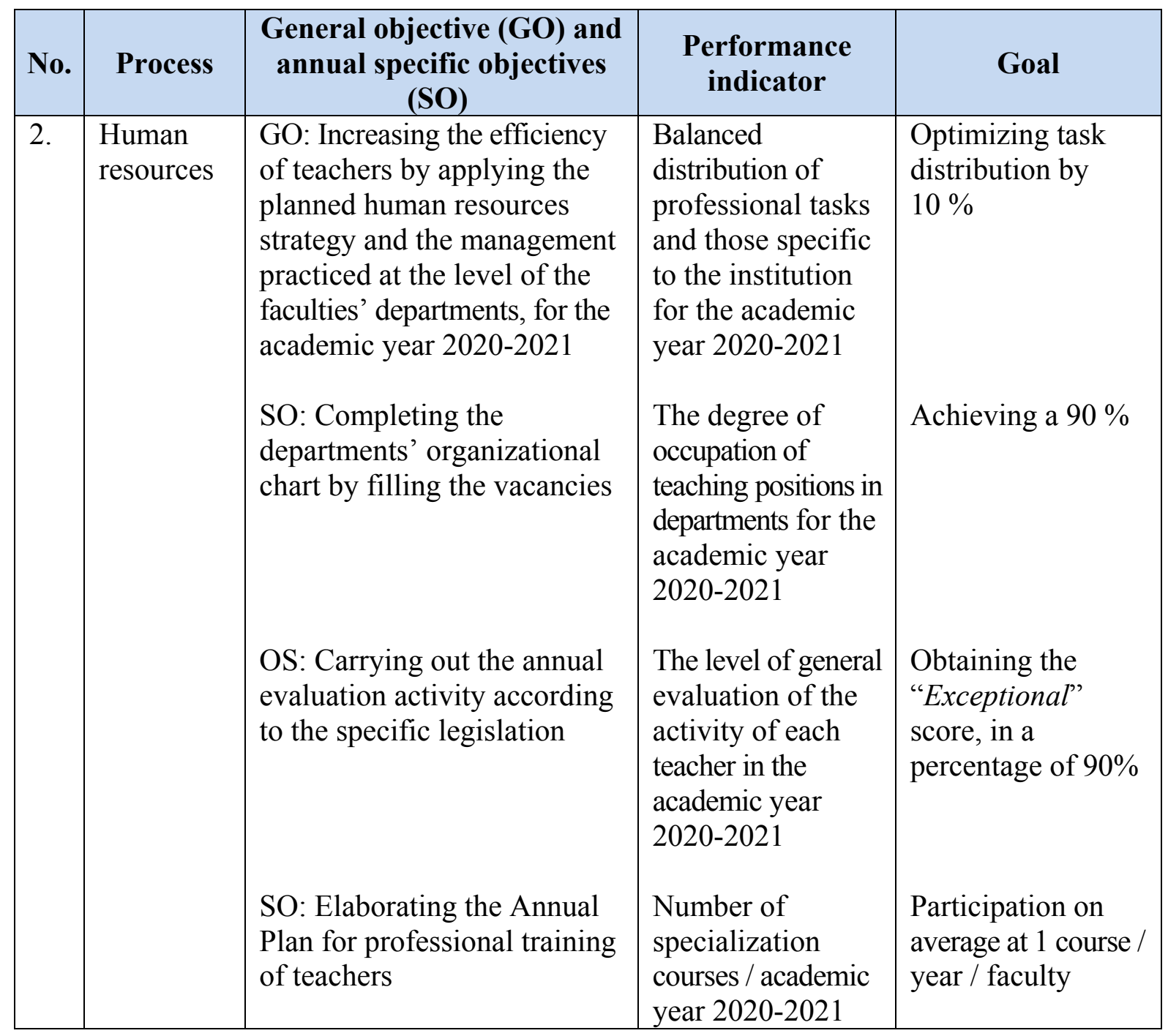

\section{Analysis of performance indicators}

The analysis of the performance indicators involves the comparison between the established reference periods of the proposed goals and the determination of the deviation of each result. In case of negative deviations, the analysis will lead to decisions by responsible factors that will be expressed in action plans to improve performance indicators that have not reached their intended goal.
Given that the current educational process is dynamic and student-centered, which implies a shared responsibility for learning outcomes by teachers and students, it means that measures to improve performance indicators must also be consciously addressed and constructive. Evaluation theory provides effective methods and techniques for this purpose. 
Table no. 4

Analysis of performance indicators

General objective: Increasing the performance of educational management in the university

\begin{tabular}{|c|c|c|c|c|c|c|}
\hline Indicators & Formula & $\begin{array}{l}\text { Aimed } \\
\text { Target }\end{array}$ & $\begin{array}{c}\text { Year } \\
2019 / \\
2020\end{array}$ & $\begin{array}{c}\text { Year } \\
2020 / \\
2021\end{array}$ & Deviation & Analysis \\
\hline $\begin{array}{l}\text { The level of } \\
\text { physical and } \\
\text { sports training } \\
\text { of the students } \\
\text { at the final } \\
\text { annual } \\
\text { evaluation } \\
2020-2021\end{array}$ & $\begin{array}{l}\text { Sports scales } \\
\text { are divided into } \\
5 \text { levels: } \\
\text { Exceptional, } \\
\text { Very good, } \\
\text { Good, } \\
\text { Satisfactory } \\
\text { and } \\
\text { Unsatisfactory } \\
\end{array}$ & $85 \%$ & $80 \%$ & $90 \%$ & $+5 \%$ & $\begin{array}{l}\text { Increased } \\
\text { involvement of } \\
\text { teachers and } \\
\text { students has led to } \\
\text { better results than } \\
\text { in the previous } \\
\text { year. }\end{array}$ \\
\hline $\begin{array}{l}\text { The level of } \\
\text { participation in } \\
\text { the physical } \\
\text { and sports } \\
\text { training } \\
\text { activities } \\
\text { planned in the } \\
\text { academic year } \\
2020-2021\end{array}$ & $\begin{array}{l}\text { Total number } \\
\text { of truancies/ } \\
\text { Total number } \\
\text { of hours }\end{array}$ & $90 \%$ & $90 \%$ & $80 \%$ & $-10 \%$ & $\begin{array}{l}\text { The decrease in } \\
\text { participation in the } \\
\text { planned classes } \\
\text { was due to the } \\
\text { problems caused } \\
\text { by the spread of the } \\
\text { Covid-19 virus, but } \\
\text { this problem was } \\
\text { compensated by } \\
\text { the corrective } \\
\text { measures }\end{array}$ \\
\hline $\begin{array}{l}\text { The results } \\
\text { obtained at the } \\
\text { sports } \\
\text { competitions } \\
\text { and contests } \\
\text { planned in the } \\
2020-2021 \\
\text { calendar }\end{array}$ & $\begin{array}{l}\text { Total number } \\
\text { of I }{ }^{\text {st }} \text { place } \\
\text { prizes / Total } \\
\text { number of } \\
\text { prizes }\end{array}$ & $\begin{array}{l}\text { First } \\
\text { place in } \\
\text { at least } \\
75 \% \text { of } \\
\text { the total } \\
\text { particip } \\
\text { ations }\end{array}$ & $70 \%$ & $75 \%$ & $0 \%$ & $\begin{array}{l}\text { The target was } \\
\text { reached due to the } \\
\text { assurance of an } \\
\text { efficient } \\
\text { management of the } \\
\text { activities and the } \\
\text { complete assurance } \\
\text { of the training } \\
\text { conditions }\end{array}$ \\
\hline $\begin{array}{l}\text { Insuring the } \\
\text { acquisition } \\
\text { percentage to } \\
\text { bring up the } \\
\text { facilities }\end{array}$ & $\begin{array}{l}\text { Allocated } \\
\text { financial } \\
\text { resources / } \\
\text { planned } \\
\text { financial } \\
\text { resources }\end{array}$ & $100 \%$ & $80 \%$ & $100 \%$ & $0 \%$ & $\begin{array}{l}\text { The } 100 \% \\
\text { completion of the } \\
\text { facilities is due to } \\
\text { the integral } \\
\text { assurance of the } \\
\text { financial resources } \\
\text { and to the } \\
\text { achievement of an } \\
\text { efficient } \\
\text { management of the } \\
\text { acquisitions }\end{array}$ \\
\hline
\end{tabular}




\begin{tabular}{|c|c|c|c|c|c|c|}
\hline \multicolumn{7}{|c|}{$\begin{array}{c}\text { General objective: Increasing the performance of educational management in the } \\
\text { university }\end{array}$} \\
\hline Indicators & Formula & $\begin{array}{l}\text { Aimed } \\
\text { Target }\end{array}$ & $\begin{array}{c}\text { Year } \\
2019 / \\
2020\end{array}$ & $\begin{array}{c}\text { Year } \\
2020 / \\
2021\end{array}$ & Deviation & Analysis \\
\hline $\begin{array}{l}\text { Balanced } \\
\text { distribution of } \\
\text { professional } \\
\text { tasks and those } \\
\text { specific to the } \\
\text { institution for } \\
\text { the academic } \\
\text { year } 2020- \\
2021\end{array}$ & $\begin{array}{l}\text { Total number } \\
\text { of tasks/Total } \\
\text { number of } \\
\text { teachers }\end{array}$ & $10 \%$ & $10 \%$ & $10 \%$ & $0 \%$ & $\begin{array}{l}\text { The } 10 \% \text { increase } \\
\text { for } 2020-2021 \\
\text { academic year was } \\
\text { constant compared } \\
\text { to the previous } \\
\text { year, due to a } \\
\text { rational approach } \\
\text { to the allocation of } \\
\text { additional } \\
\text { workloads } \\
\end{array}$ \\
\hline $\begin{array}{l}\text { The degree of } \\
\text { occupation of } \\
\text { teaching } \\
\text { positions in } \\
\text { departments } \\
\text { for the } \\
\text { academic year } \\
2020-2021\end{array}$ & $\begin{array}{l}\text { No. of } \\
\text { positions } \\
\text { occupied / no. } \\
\text { of existing } \\
\text { positions in the } \\
\text { organizational } \\
\text { chart }\end{array}$ & $90 \%$ & $75 \%$ & $92 \%$ & $0.2 \%$ & $\begin{array}{l}\text { The } 17 \% \text { increase } \\
\text { in the number of } \\
\text { positions compared } \\
\text { to } 2019 \text { is due to a } \\
\text { better management } \\
\text { at the level of } \\
\text { department } \\
\text { directors }\end{array}$ \\
\hline $\begin{array}{l}\text { The level of } \\
\text { general } \\
\text { evaluation of } \\
\text { the activity of } \\
\text { each teacher } \\
\text { for the } \\
\text { academic year } \\
2020-2021\end{array}$ & $\begin{array}{l}\text { The specific } \\
\text { instructions } \\
\text { divide the } \\
\text { evaluation into } \\
5 \text { levels: } \\
\text { Exceptional, } \\
\text { Very good, } \\
\text { Good, } \\
\text { Satisfactory } \\
\text { and } \\
\text { Unsatisfactory } \\
\end{array}$ & $90 \%$ & $80 \%$ & $90 \%$ & $+10 \%$ & $\begin{array}{l}\text { The increase is due } \\
\text { to the participation } \\
\text { of teachers in } \\
\text { specialization } \\
\text { courses and their } \\
\text { continuous training }\end{array}$ \\
\hline $\begin{array}{l}\text { Number of } \\
\text { specialization } \\
\text { courses / } \\
\text { academic year } \\
2020-2021\end{array}$ & $\begin{array}{l}\text { According to } \\
\text { the list of } \\
\text { offers from the } \\
\text { higher echelon } \\
\text { and the } \\
\text { existing offer } \\
\text { in the civilian } \\
\text { environment } \\
\end{array}$ & $\begin{array}{l}1 \text { class / } \\
\text { year / } \\
\text { faculty }\end{array}$ & 0.90 & 1.1 & +0.1 & $\begin{array}{l}\text { The increase is due } \\
\text { to the greater } \\
\text { interest of teachers } \\
\text { for specialization, } \\
\text { implicitly in } \\
\text { professional } \\
\text { promotion }\end{array}$ \\
\hline
\end{tabular}

\section{Discussions and conclusions}

The paper provides a model for evaluating performance in the education system using key performance indicators, using as a method of analysis and research the procedural approach, this being one of the principles of quality management.

The overall processes of a military higher education institution were taken into account, the customization being made only 
from this point of view, the other elements of content and analysis being common for any higher education institution.

The stages of analysis of the study object were rigorously elaborated, having a logical chain of establishing the key performance indicators and content focused on the issue. The target of the indicators was estimated fictitiously for the academic year 2020-2021, and the analysis of deviations was also performed theoretically in order to demonstrate the validity of the model.

The advantages of this study are the following:

- the procedural approach allowed the identification of the processes specific to the educational system on the three categories and their inclusion in the map of processes (Figure no. 1), which allowed an easy understanding of the general information flow;

- once the general and specific objectives for each process were established, key performance indicators could be formulated in accordance with the identified processes;

- the analysis of deviations from the proposed goal allows formulating measures to improve unfulfilled indicators, with implications for other processes, which gives the educational system a dynamic character.

\section{REFERENCES}

Bâtcă-Dumitru, C. G., Sahlian, D. N., \& Şendroiu, C. (2019). Managementul performanței. Bucharest: Editura Ceccar.

Dumitrașcu, V., \& Ciupitu, S. A. (2013). Bazele managementului. Aspecte comportamentale ale performanței. Bucharest: Editura Prouniversitaria.

"Nicolae Bălcescu" Land Forces Academy. (2020). Objective, available at: https://www.armyacademy.ro/prezentare obiective.php. accessed on 21 November 2020.

Romanian Agency for Quality Assurance in Higher Education. (2006). Metodologia de evaluare externă, standardele, standardele de referinţă şi lista indicatorilor de performanţă a Agenţiei Române de Asigurare a Calitătii în Învăţământul Superior. Bucharest, available at: https://www.aracis.ro/wp-content/uploads/2019/07/Metodologie de evaluare externa.pdf, accessed on 21 November 2020.

Romanian Standardization Association. SR EN ISO 9000:2006. Sisteme de management al calității. Principii și vocabular, available at: https://magazin.asro.ro/ro/standard/112306, accessed on 21 November 2020. 